\title{
Specificity of lymphocytotoxic autoantibodies (LCAbs) found in the serum of leprosy patients: Class I MHC antigens
}

\author{
FAWZIA N RASHEED, ${ }^{* *}$ MARY LOCNISKAR, ${ }^{*}$ \\ D J MCCLOSKEY,* RUMINA S HASAN, $\dagger$ \\ T J CHIANG, $\ddagger$ PATRICIA ROSE, $\S$ \\ R DE SOLDENHOFF, $₫$ H FESTENSTEIN* \& \\ K P W J McADAM* \\ *Department of Clinical Sciences, The London School of Hygiene \\ and Tropical Medicine and The London Hospital, London, England; \\ $\dagger$ The Aga Khan University and $\ddagger$ The Marie Adelaide Leprosy \\ Centre, Karachi, Pakistan; §The Public Health Clinic, Georgetown, \\ Guyana; The Ministry of Health, Lusaka, Zambia
}

Accepted for publication 12 July 1990

\begin{abstract}
Summary Lymphocytotoxic autoantibodies (LCAbs) of the IgM class have been identified in patients with borderline tuberculoid (BT) and borderline lepromatous (BL) leprosy with Type I reactions (I) as well as lepromatous leprosy (LL) patients with erythema nodosum leprosum reactions (ENL). The observation that lymphocytotoxic activity (LCA) was reduced in the presence of platelets led us to determine whether LCAbs had specificities for Class I Major Histocompatibility Complex (MHC) determinants. Absorption of LCA positive sera with platelets, classically used to deplete Class I specific lymphocytotoxic antibodies, reduced LCA towards autologous as well as allogeneic target cells. This was true for LCA positive sera from all patient classifications (group BT in the autologous system, $p<0.01$; in all other patient groups, $p<0.001$ ). Introducing B- $2 \mathrm{~m}$ to cytotoxicity assays only marginally reduced LCA when added at high concentrations $(5 \mathrm{mg} / \mathrm{ml})$. An anti-Class I MHC antiserum which blocked the lytic activity of Class I tissue typing sera did not inhibit lymphocytotoxic activity. The data indicate that LCAbs while absorbed by platelets, are not specific for the Class I MHC antigens. The autoantigen recognized by these autoantibodies therefore remains to be identified.
\end{abstract}

\section{Introduction}

Leprosy has been termed an immunological disease because much of the pathology, particularly of leprosy reversal or Type I reactions (I) and erythema nodosum leprosum

** Correspondence: Dr F N Rasheed, ICDDRB, GPO Box 128, Dhaka 1000, Bangladesh. 
(ENL) reactions is associated with tissue and nerve autodestruction and not directly with the presence of Mycobacterium leprae.

Lymphocytotoxic activity (LCA) has been demonstrated in the sera of leprosy patients. ${ }^{1-4}$ Complement dependent IgM autoantibodies have been found to be responsible for this activity. Elevated levels of these antibodies are present in the sera of leprosy patients undergoing either clinical hypersensitivity Type I or ENL reactions compared to leprosy patients without these reactions or control subjects. ${ }^{4}$ These antibodies function in a temperature dependent manner. When tested at $37^{\circ} \mathrm{C}, 32 \%$ of sera derived from BT leprosy patients with a history of Type I reactions were positive for LCA $(n=24)$. At $15^{\circ} \mathrm{C}$ the prevalence of LCA in the same sera increased to $88 \%$. The difference in reactivity at these two temperatures is similar to and also significant in patient groups $\mathrm{LL}+\mathrm{ENL}$ and $\mathrm{BL}+\mathrm{I}$. We assume that these antibodies have low affinity binding properties at $37^{\circ} \mathrm{C}$ and that the reduced temperature conditions of $15^{\circ} \mathrm{C}$ permit a closer physical association between these antibodies and their antigen/s. It is not yet known how these antibodies are stimulated, which target autoantigens they bind to and whether or not they are of immunoregulatory or pathological importance in these reactional states.

Numerous reports cite examples of immunoregulatory functions attributed to antibodies which bind to lymphocyte determinants. To illustrate, antibodies have been identified which induce the secretion of interleukin-2, stimulate $T$ cell proliferation and cytotoxic T cell activation. ${ }^{5}$ Keizer et al. ${ }^{6}$ deseribe antibodies which bind to leucocyte function associated antigen-1 (LFA-1) which acts as a cell adhesion molecule mediating a variety of cell-cell interactions. The binding of one monoclonal antibody to LFA-1 alpha chain stimulates these interactions while others binding to the same molecule but possibly to different epitopes, inhibit cell aggregate formation. ${ }^{6}$ To assess the potential role of LCAbs it is clearly important to define the antigen/s to which they bind.

LCA is also present in sera of patients with systemic lupus erythematosus (SLE) and correlates with the clinical course of the disorder. ${ }^{7}$ LCA in SLE sera was reported to disappear upon absorption with platelets. ${ }^{8}$ LCA in these patients was seen to be associated with anti B-2m antibodies which were evaluated to be $\mathrm{IgG}^{8,9}$

The results of investigating the specificity of LCAbs in the sera of leprosy patients for B-2m and the Class I MHC complex itself are presented in this paper. We have selected LCA positive sera from patient groups previously determined to have significantly raised levels of this activity $(\mathrm{LL}+\mathrm{ENL}, \mathrm{BL}+\mathrm{I}$ and BT $+\mathrm{I})$. The specificity of LCAbs from these sera as well as LCA positive sera from other patient groups across the leprosy spectrum have been compared to endemic controls.

\section{Materials and methods}

\section{Patients and controls}

Sera were processed from patients diagnosed with leprosy and endemic controls at the Public Health Clinic Georgetown, Guyana; Liteta Hospital, Lusaka, Zambia; and the Marie Adelaide Leprosy Centre, The Aga Khan University, Karachi, Pakistan. All leprosy patients were classified using the clinical and bacteriological criteria specified by the Ridley and Jopling Scale. ${ }^{10,11}$ Patients in hypersensitivity reactions either at the time of 
bleeding or up to a year prior to bleeding were classified separately. Male and female patient and control subjects ranged from 10 to 65 years of age.

\section{Microlymphocytotoxicity assay}

The details of this method have been described elsewhere. ${ }^{4}$ In brief, lymphocytes were isolated from 50 individuals selected to represent most known HLA-A, -B, and -C antigens. Test sera diluted 1:2 in complement fixation test media ((CFT) Oxoid Ltd, England) were dispensed into wells of a Terasaki microtitre plate and incubated with lymphocytes for $30 \mathrm{~min}$ at $15^{\circ} \mathrm{C}$. Rabbit complement was added to each well, followed by a further incubation of $2 \frac{1}{2} \mathrm{~h}$ at $15^{\circ} \mathrm{C}$. The percentage of lymphocytotoxicity in each well was assessed using phase contrast microscopy. A pool of noncytotoxic AB sera was used as a negative control on each plate. Lymphocytotoxicity was scored using a 6 point scale from 0 to 8 . A score of 1 corresponds to a killing of $10-20 \%$ of lymphocytes; a score of $2=20-40 \% ; 4=40-60 \% ; 6=60-80 \% ; 8=80-100 \%$. LCA positive sera which are characterized in this paper reacted to $>75 \%$ of the panel of donors tested.

\section{Serum absorption with platelets}

Platelets from 100 randomly selected individuals were pooled. These were washed thoroughly with phosphate buffered saline. Washed packed platelets were mixed with sera at a ratio of $1: 2$ for one hour on ice. Two separate absorptions, were performed on each serum sample with 2 aliquots of platelets. Sera were tested before and after absorption with platelets against allogeneic lymphocytes derived from 10 donors or in 5 replicates against autologous lymphocytes.

\section{Introduction of $B-2 m$ to the microlymphocytotoxicity assay}

A total of 35 test sera from leprosy patients with positive LCA and endemic controls with negative LCA, were used. The sera were diluted $1: 2$ in CFT containing varying concentrations (seven 10-fold dilutions from $5 \mathrm{mg} / \mathrm{ml}$ to $0.5 \mathrm{ng} / \mathrm{ml}$ ) of B-2m (Sigma Chemical Co. Ltd, England). Sera and B-2m were preincubated for $2 \mathrm{~h}$. Sera preincubated with CFT alone were used as a negative control. The sera were then tested without further dilution against lymphocytes derived from 10 allogeneic donors in the microlymphocytotoxicity assay.

\section{Antiserum for B-2m/Class I MHC antigens}

A commercially available chicken polyclonal antiserum against B-2m (Serotec, USA) when tested, was found not only to bind to B-2m but also to the Class I complex. In our hands, lymphocytes when preincubated with this antiserum, were found to no longer be lysed by Class I specific polymorphic tissue typing antisera. The polymorphic HLA-Class I reagents used were well characterized tissue typing reagents used in the Class I Tissue Typing Laboratory, The London Hospital Medical College. Lymphocytes from 4 different donors of known tissue type were tested pre and post incubation with either this anti-Class I or control noncytotoxic AB serum against the same set of 35 sera. As an additional control, five HLA Class I typing sera were tested blind against these 
lymphocytes alongside leprosy LCA positive sera in the microlymphocytotoxicity assay. The results were read independently by the $\mathrm{ABC}$ Tissue Typing Laboratory at the London Hospital.

\section{Results}

\section{Absorption of LCA positive sera with platelets}

To test if Class I antigens were the target for LCA, platelets were used to adsorb possible anti-Class I antibodies from LCA positive sera. Absorption of LCA positive sera with platelets significantly reduced LCA in all patient groups (Figures $1(\mathrm{a})$ and (b)) irrespective of whether the target lymphocytes were allogeneic or autologous in origin. All groups demonstrated a significant reduction $(p<0.001)$ in LCA towards allogeneic cells after sera were treated with platelets (Figure 1(a)). A significant reduction in LCA was also seen in patient group BT $(p<0.01)$ and other groups $(p<0.001)$ when tested in the autologous system (Fig 1b).

\section{The effect of $B-2 m$ on $L C A$}

B-2 $\mathrm{m}$ is present on the membrane of all nucleated cells and platelets where it is bound non covalently to HLA Class I molecules. To test whether lymphocytotoxic antibodies were directed against B-2m, LCA positive sera were pre-incubated with the B- $2 \mathrm{~m}$ to absorb anti-B-2m antibodies. The results of using B- $2 \mathrm{~m}$ at $0.5 \mathrm{ng} / \mathrm{ml}$ and $5 \mathrm{mg} / \mathrm{ml}$ concentrations

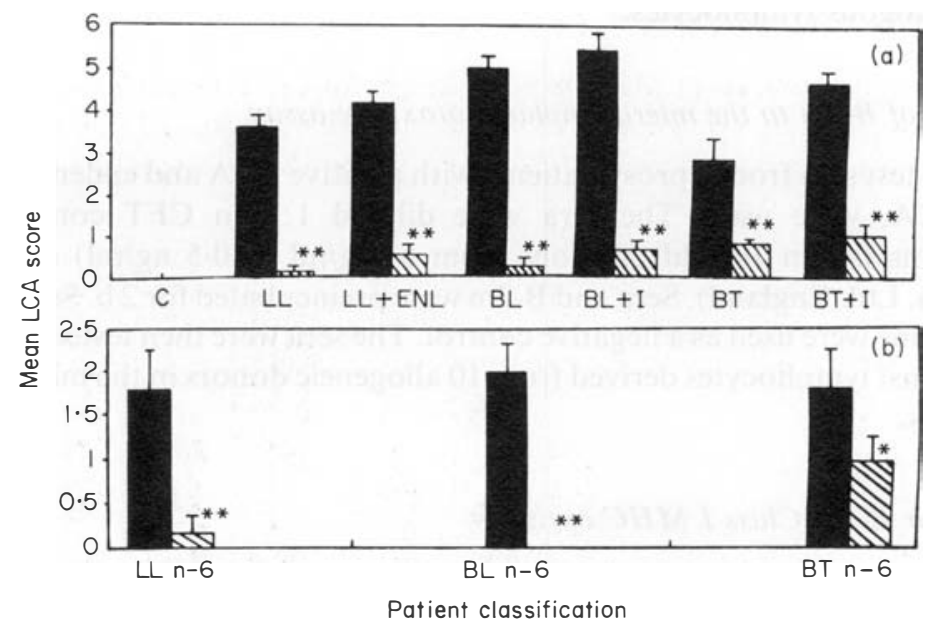

Figure 1. The effect of absorption of sera with platelets on LCA. (a) Allogeneic system: Five sera from each patient group were tested against lymphocytes from 10 different donors before (blackened bars) and after (hatched bars) absorption with platelets. (b) Autologous system: Six sera from each patient group were tested in 5 replicates against autologous lymphocytes before (blackened bars) and af ter (hatched bars) absorption with platelets. The mean LCA for each individual serum was calculated and the overall means of each patient group are presented. C, endemic control sera without LCA. Patient groups with LCA: LL, lepromatous leprosy; BL, borderline lepromatous leprosy; BT, borderline tuberculoid; I, Type I reaction; ENL, erythema nodosum leprosum. ${ }^{*}=p<0.001,{ }^{* *}=p<0.01$ (paired $\mathrm{T}$ test). The standard error of the mean are indicated for each group. 


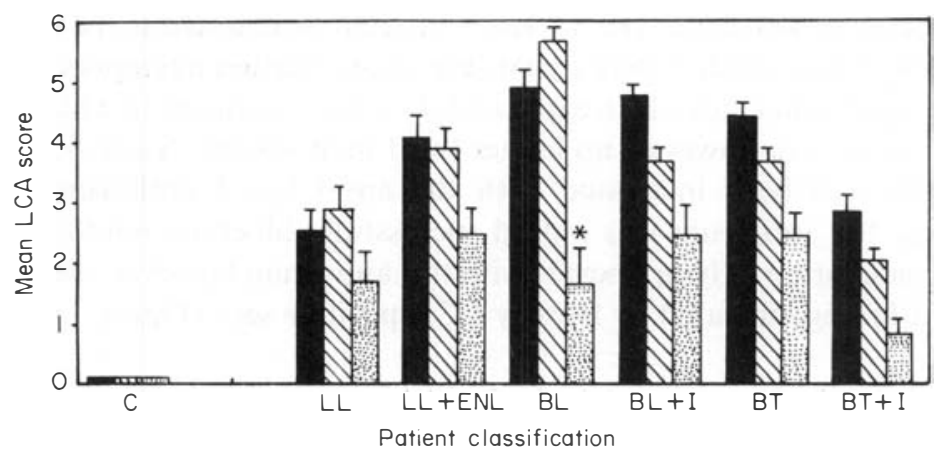

Figure 2. The effect of B-2m on LCA. Five sera from each patient group were tested against allogeneic lymphocytes from 10 diff erent donors. LCA is compared between untreated sera (blackened bars) and sera preincubated with either $0.5 \mathrm{ng} / \mathrm{ml} \mathrm{B}-2 \mathrm{~m}$ (hatched bars) or $5 \mathrm{mg} / \mathrm{ml} \mathrm{B}-2 \mathrm{~m}$ (stippled bars). The mean LCA for each test serum was calculated and the overall means for each group are expressed with the standard error of the mean. C, endemic control sera negative for LCA, leprosy patient groups positive for LCA: LL, lepromatous leprosy; BL, borderline lepromatous; BT, borderline tuberculoid; I, Type I reaction; ENL, erythema nodosum leprosum. ${ }^{*}=p<0.01$ (paired $\mathrm{T}$ test).

are shown (Figure 2). Data for the intermediate dilutions tested are not shown since they were not different from pretreatment LCA. At a concentration of $5 \mathrm{mg} / \mathrm{ml}, \mathrm{B}-2 \mathrm{~m}$ marginally but not significantly reduced LCA in groups $L L, L L+E N L, B L+I, B T$, $\mathrm{BT}+\mathrm{I}$ and reduced LCA significantly in BL patients $(p<0 \cdot 01)$.

\section{The effect of blocking the Class I MHC on LCA}

To determine whether Class I MHC was the target for LCA, target lymphocytes were pre incubated with an anti-Class I antisera before incubation with LCA positive sera. To ensure that this antiserum would indeed block Class I MHC expression, control sera of

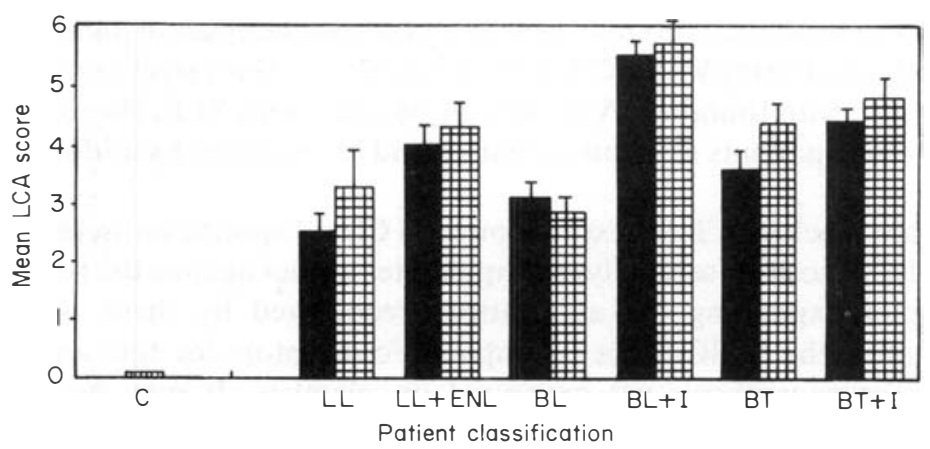

Figure 3. The effect of blocking class I MHC expression of lymphocytes on LCA. Five lymphocytotoxic sera from each patient group were tested against lymphocytes from 5 different individuals bef ore (blackened bars) and after (blocked bars) incubation with anti-Class I antiserum. The individual means for each serum were calculated. The means and standard error of the mean of each patient group are presented. C, LCA negative endemic controls, Leprosy patient groups positive for LCA: LL, lepromatous leprosy; BL, borderline lepromatous; BT, borderline tuberculoid; I, Type I reaction; ENL, erythema nodosum leprosum. 
known specificity for particular HLA Class I antigens were tested in the microlymphocytotoxicity assay. These tissue typing sera discriminated between lymphocytes in that they lysed only those lymphocytes which expressed the Class I antigens to which they had been raised. These same sera however, no longer lysed their specific lymphocyte targets once the target cells had been incubated with the anti-Class I antiserum. We therefore concluded that the antiserum was indeed successfully blocking binding to the Class I complex. Preincubation of lymphocytes with this antiserum however, made no difference to subsequent killing mediated by leprosy LCA positive sera (Figure 3).

\section{Discussion}

LCAbs in the sera of leprosy patients appear to recognize determinants common to both platelets and lymphocytes. ${ }^{4}$ We have shown previously that serum LCA shows broad reactivity towards target lymphocytes derived from 50 individuals chosen for their expression of most known HLA antigens. ${ }^{4}$ These data indicate that the antigen recognized is common to lymphocytes of most individuals. Very occasionally, target cells from some individuals are not lysed by these sera. It is possible that on the odd occasion when LCA is reduced or absent, that the antigen/s recognized by these antibodies are missing or masked. The observation that LCAbs are absorbed by platelets led us to speculate that the expression of the autoantigen may be linked or associated with the expression of the Class I complex. Changes in the alloantigenic domains may induce a conformational change of an associated and common antigen. Occasionally, such a change in conformation may prevent this common antigen from being recognized by LCAbs.

B-2m exists as both a free and bound molecule. ${ }^{12,13}$ The introduction of free B-2m into the microcytotoxicity assay with LCA positive sera did not significantly reduce LCA in most patient groups. At the high concentration of $5 \mathrm{mg} / \mathrm{ml}, \mathrm{B}-2 \mathrm{~m}$ significantly reduced LCA in patients with BL. The variation in this assay as in all others involving sera with different levels of LCA and target cells which illicit different levels of response is high. The reduction of LCA in BL patients may well be a non-specific effect of high concentration of B-2m physically interfering with LCAbs from binding to their target antigens. In contrast, Revillhard et al., ${ }^{8}$ who found LCA in 50\% of patients with SLE, showed that in half of these LCA positive patients that this activity could be inhibited by adding as little as $1 \mathrm{ng}$ B-2m.

The fact that blocking Class I expression with Class I specific antisera had no effect on the ability of LCA positive sera to lyse lymphocytes argues against the possible role of the Class I complex expressing the autoantigen recognized by these antibodies. Many antigens including the MHC Class I complex, Fc receptors for IgG and IgE as well as common membrane antigens are expressed on platelets. It may be that a common membrane bound protein present on platelets as well as lymphocytes could be responsible for this activity. An alternative approach to concluding this investigation is to immunoblot sonicated platelet and lymphocyte antigens separated on polyacrylamide gels with LCA positive sera to identify at the molecular weight level the antigen bound. This method is currently being employed in our laboratories. 


\title{
Acknowledgments
}

Our thanks to Mr Colin Brown and Mr John Smith at the London Hospital for cross checking some of the results in this paper. Dr F N Rasheed was supported by the British Council.

\section{References}

1 Kriesler JM, Arnaiz A, Perez B, Bootello A. Lymphocytotoxins in leprosy. Int J Lepr, 1975; 43: 91.

2 Serjeantson S, Dry P. Lymphocytotoxins in leprosy in asymptomatic hepatitis B virus infection. Clin exp Immunol, 1980; 39: 289.

${ }^{3}$ Naik S, Kumar B, Kaur S, Sehgal S. Lymphocytotoxic antibodies in leprosy. Ind J Lepr, 1987; 51: (No. 1 Suppl) Sect II.

4 Rasheed FN, Locniskar M, McCloskey DJ, Hasan RS, Chiang TJ, Rose P, De Soldenhoff R, Festenstein H, McAdam KPWJ. Lymphocytotoxic activity in the sera of leprosy patients. Clin exp Immunol, 1989; 76: 391.

5 Samuelson E, O’Shea JJ, Hoa-Lung, Ross P, Urdahl KE, Klausner RD, Bluestone J. T cell antigen receptor phosphorylation induced by an anti-receptor antibody. J Immunol, 1987; 139: 2708.

6 Keizer GD, Visser W, Vliem M, Figdor CG. A monoclonal antibody (NK1-L16) directed against a unique epitope on the alpha-chain of human leukocyte function associated antigen 1 induces clonotypic cell-cell interactions. J Immunol, 1988; 140: 1393.

7 Michlmayr G, Pathouli C, Huber C, Huber H. Antibodies for T lymphocytes in systemic lupus erythematosus. Clin exp Immunol, 1976; 24: 18.

8 Revillhard JP, Vincent G, Rivera S. Anti Beta-2 microglobulin lymphocytotoxic autoantibodies in systemic lupus erythematosus. J Immunol, 1979; 122: 614 .

9 Ooi BS, Ooi YM, Pesce AJ, Pollack VE. Antibodies to B-2 microglobulin in the sera of patients with systemic lupus erythematosus. Immunol, 1977; 33: 535.

10 Ridley DS, Jopling WH. A classification of leprosy for research purposes. Le pr Rev, 1962; 33: 119.

11 Ridley DS, Jopling WH. Classification of leprosy according to immunity-a five group system. Int $J$ Lepr, 1966; 33: 255.

12 Grey NM, Kubo RT, Colon SM, Poulik MD, Springer T, Turner M, Strominger JL. The small subunit of HL-A antigens in B-2 microglobulin. $J$ exp Med, 1973; 138: 1608.

13 Smithies O, Poulik MD. Imitation of protein synthesis at an unusual position in an immunoglobulin gene. Science, 1972; 175: 187.

\section{La spécificité des auto-anticorps (LCAbs) trouvés dans les sérums des patients de lèpre}

\author{
FAWZIA N RASHEED, MARY LOCNISKAR, D J MCCLOSKEY, RUMINA S \\ HASAN, $T$ J CHIANG, PATRICIA ROSE, $R$ DE SOLDENHOFF, $H$ \\ FESTENSTEIN ET K P W J MCADAM
}

Sommaire - Auto-anticorps lymphocytoxiques (LCAbs) du type IgM ont été identifiés dans des patients avec des cas limites de lèpre tuberculeuse (BT) et de lèpre lépromateuse (BL) avec des réactions du Type I (I), et aussi dans des patients avec lèpre lépromateuse avec des réactions d'érythème lépreux noueux (ENL). La disminution observée dans l'activité lymphocytotoxique (LCA) en présence des plaquettes nous a mené à déterminer si les LCAbs avaient des spécificités pour des déterminants de la classe I du système majeur d'histocompatibilité. L'absorption des sérums LCA-positifs avec des plaquettes, méthode utilisée traditionellement pour épuiser les anticorps lymphocytotoxiques spécifiques à la classe I, a réduit la LCA vers des cellules-cible autologues et aussi allogéniques. Cela a été le cas avec tous les sérums LCA-positifs de tous les patients de différents groupes (dans le groupe BT du système autologue, $\mathrm{p}<0,01$; dans tous les autres groupes 
de patients, $\mathrm{p}<0,001)$. L'introduction de $\mathrm{B}-2 \mathrm{~m}$ dans les essais de cytotoxicité a seulement réduit légèrement la LCA en l'utilisant à hautes concentrations $(5 \mathrm{mg} / \mathrm{ml})$. Un antisérum anti-MHC classe I qui bloquait l'activité lytique des sérums classifiants des tissus de la classe I n'a pas réduit l'activité cytotoxique. Les données indiquent que, bien que les LCAbs sont absorbés par des plaquettes, ils ne montrent pas de spécificité vers les antigènes MHC classe I. Il reste donc à identifier l'autoantigène reconnu par ces auto-anticorps.

\title{
La especifidad de los autoanticuerpos (LCAbs) linfocitotóxicos presentes en los sueros de pacientes con lepra
}

\author{
FAWZIA N RASHEED, MARY LOCNISKAR, D J MCCLOSKEY, RUMINA S \\ HASAN, $\mathrm{T} J$ CHIANG, PATRICIA ROSE, R DE SOLDENHOFF, $\mathrm{H}$ \\ FESTENSTEIN Y K P W J MCADAM
}

Resumen - Se han descubierto autoanticuerpos linfocitotóxicos (LCABs) de tipo IgM en pacientes con reacciones del Tipo I (I) con casos inciertos de lepra tuberculoide (BTL) y casos inciertos de lepra lepromatosa (BLL), y también en pacientes con lepra lepromatosa (LL) con reacciones de eritema leproso nudoso (ENL). La disminución observada en la actividad linfocitotóxico en presencia de plaquetas nos llevó a intentar establecer si los LCAbs tenían actividades específicas hacia los determinantes de la clase I del sistema mayor de histocompatibilidad (MHC). La absorción de sueros LCA-positivos con plaquetas, método tradicionalmente utilizado para agotar los anticuerpos linfocitotóxicos específicos a la clase I, disminuyó la LCA hacia células-blanco autólogas y también alogéneas. Este fue el caso con todos los sueros LCA-positivos de los pacientes de cada grupo (en el grupo BT del sistema autólogo, $p>0,01$; en todos los demás grupos de pacientes, $p<0,001)$. La introducción de B-2m en los ensayos de citotoxicidad sólo redu jo ligeramente la LCA al ser utilizado en altas concentraciones $(5 \mathrm{mg} / \mathrm{ml})$. Un antisuero anti-MHC clase I que impedía la actividad lítica de los sueros determinantes de tejidos de la clase I no inhibió la actividad linfocitotóxica. Estos datos sugieren que, mientras que si son absorbidos por las plaquetas, la actividad de los LCABs no es específica a los antígenos del MHC de la clase I. Por lo tanto, queda por identificar el autoantígeno que reconocen estos autoanticuerpos. 